\title{
Home dampness, moulds and their influence on respiratory infec- tions and symptoms in adults in Finland
}

\author{
I. Pirhonen*, A. Nevalainen**, T. Husman*, J. Pekkanen*
}

\begin{abstract}
Home dampness, moulds and their influence on respiratory infections and symptoms in adults in Finland. I. Pirhonen, A. Nevalainen, T. Husman, J. Pekkanen. CERS Journals Ltd 1996.

ABSTRACT: The aim of this study was to analyse the prevalence of mouldy homes and their association with respiratory symptoms and diseases in a subarctic climate.

A questionnaire was mailed to a random sample of 2,000 males and females, aged 25-64 yrs, living in the county of Kuopio, Finland. A total of 1,521 (76\%) responded and 1,460 were selected for the final analysis.

The prevalence of homes with visible mould was $4 \%$; with the odour of mould $5 \%$; with damp spots, visible mould or the odour of mould $15 \%$; and with moisture/water damage, damp spots, visible mould or the odour of mould $23 \%$. The number of reports of bronchitis, common cold, atopy, allergic rhinitis, rhinitis, fever and chills, hoarseness, fatigue, difficulties in concentration, lumbar backache and stomach ache were strongly associated with living in a damp home. Bronchitis, hoarseness and difficulties in concentration had the strongest associations, with adjusted odds ratios (95\% confidence limits) of: 2.04 (1.49-2.78), 2.23 (1.37-3.63) and $2.17(1.35-3.50)$, respectively. After controlling for a possible reporting bias by excluding those subjects reporting lumbar bachache and recurrent stomach pain, eye irritation and tiredness remained significant.

In conclusion, living in a home with mould problems may increase the risk of respiratory infections and symptoms in adults.

Eur Respir J., 1996, 9, 2618-2622.
\end{abstract}

Depts of *Environmental Epidemiology,
and **Environmental Microbiology, National and $* *$ Environmental Microbiology, National
Public Health Institute, Kuopio, Finland.

Correspondence: I. Pirhonen

National Public Health Institute

PL 95, 70701 Kuopio

Finland

Keywords: Home dampness

moulds

respiratory infections

respiratory symptoms

Received: October 271995

Accepted after revision August 171996
The quality of indoor air in homes may be influenced by many biological, chemical and physical agents, e.g. viruses, bacteria, mites, actinomycetes, fungal spores, arthropod fragments and droppings, animal and human dander, tobacco smoke, chemicals [1-3], temperature, humidity and poor ventilation $[4,5]$. There may also be as yet unknown interactions between indoor air pollutants.

During recent years, the health risks due to dampness and mould problems in homes have received considerable attention. Mould problems occur if there is excess dampness or moisture in a building. Fungi may grow on practically any building material, provided that there is sufficient moisture or condensation [6].

The concept of dampness of a building is to some extent associated with climatic factors. In the subarctic climate, building structures should be dry since the heating season is long, buildings are well-insulated, and during the cold period (three quarters of the year) the relative humidity of indoor air is low. However, moisture problems occur even in these conditions [7].

Emissions from mould growth in homes are a potential risk factor for respiratory infections and symptoms. Adverse health effects have been reported among children and adults due to dampness and moulds in buildings in Britain [8-14], The Netherlands [15, 16], USA
[17, 18], Canada [18, 19] and Scandinavia [20, 21]. A summary of some of these studies is presented in table 1. Most studies indicate that living in a damp or mouldy home is associated with respiratory infections and various other symptoms, both among children and adults. MARTIN et al. [10] found such an association in children, but not in adults.

The association between home dampness and symptoms may be caused by a reporting bias, i.e. people who are aware of the problems in the house are more likely to report the occurrence of symptoms [11]. Reporting of mould seems to be more likely in those families with an asthmatic child [14], where a child is atopic, the parents are well-educated and when they have asthma or chronic obstructive pulmonary disease (COPD) [18]. SPENGLER et al. [18], after controlling for atopy, gender, parental COPD, parental asthma and parental education, reported that there was a significant association between home dampness and respiratory symptoms among children. DALES et al. [19] indicated that atopy did not significantly influence the association in adults.

Platt et al. [12] and Dales et al. [19] controlled for possible overreporting by including a "general complainer" variable. However, this did not affect the association between the symptoms and living in damp and mouldy dwellings. 
Table 1. - Studies on home dampness, mould and their influence on respiratory diseases and other symptoms in adults

\begin{tabular}{|c|c|c|c|c|}
\hline $\begin{array}{l}\text { First author } \\
\text { [Ref] Year } \\
\text { Location }\end{array}$ & $\begin{array}{l}\text { Subjects } \\
\mathrm{n} \text {, age and methods }\end{array}$ & $\begin{array}{l}\text { Definition of home } \\
\text { dampness and mold }\end{array}$ & $\begin{array}{l}\text { Damp and mouldy } \\
\text { home - prevalence } \\
\%\end{array}$ & $\begin{array}{l}\text { Statistical significance } \\
\text { between symptoms and living } \\
\text { in damp and mouldy homes }\end{array}$ \\
\hline $\begin{array}{l}\text { BURR [9] } \\
1981 \\
\text { South Wales }\end{array}$ & $\begin{array}{l}469,20-44 \text { yrs, cross- } \\
\text { sectional questionnaire }\end{array}$ & $\begin{array}{l}\text { Asked whether bedrooms } \\
\text { were damp }\end{array}$ & 19 & $\begin{array}{l}\text { Wheezing with } \\
\text { breathlessness, } p<0.025\end{array}$ \\
\hline $\begin{array}{l}\text { MARTIN [10] } \\
1987 \\
\text { Edinburgh }\end{array}$ & $\begin{array}{l}294,19-91 \text { yrs, cross- } \\
\text { sectional questionnaire and } \\
\text { independent observation }\end{array}$ & $\begin{array}{l}\text { Independent visible mould } \\
\text { and dampness assessments }\end{array}$ & $\begin{array}{l}\text { Damp } 24 \\
\text { Mould } 17\end{array}$ & $\begin{array}{l}\text { Significant differences } \\
\text { among children, but not } \\
\text { among adults (non- } \\
\text { respiratory symptoms: } \\
\text { aches and pains, diarrhoea, } \\
\text { "nerves", headache) }\end{array}$ \\
\hline $\begin{array}{l}\text { PLATT [12] } \\
1989 \\
\text { Glasgow, } \\
\text { Edinburgh and } \\
\text { London }\end{array}$ & $\begin{array}{l}597 \text { households, cross- } \\
\text { sectional questionnaire and } \\
\text { independent observation }\end{array}$ & $\begin{array}{l}\text { Surveyors assessment of } \\
\text { dampness and mould }\end{array}$ & $\begin{array}{l}\text { Damp } 23 \\
\text { Visible mould } 46\end{array}$ & $\begin{array}{l}\text { Bad nerves, aching joints, } \\
\text { nausea-vomiting, backache, } \\
\text { blocked nose, fainting } \\
\text { spells, constipation and } \\
\text { breathlessness, p }<0.05\end{array}$ \\
\hline $\begin{array}{l}\text { WAEGEMAEKERS } \\
\text { [15] } 1989 \\
\text { Katwijk, The } \\
\text { Netherlands }\end{array}$ & $\begin{array}{l}328 \text { adults, cross- } \\
\text { sectional questionnaire }\end{array}$ & $\begin{array}{l}\text { 1. A home was damp if } \\
\text { two or more were reported } \\
\text { positive: } \\
\text { a) visible moulds } \\
\text { b) damp spots } \\
\text { c) silverfish or sow-bugs } \\
\text { (woodlice) } \\
\text { d) a stale odour } \\
\text { e) wet crawl space } \\
\text { 2. Responders own } \\
\text { perception of their home } \\
\text { (dry or damp) }\end{array}$ & $\begin{array}{l}\text { Definition 1. } 42 \\
\text { Definition 2. } 25\end{array}$ & $\begin{array}{l}\text { Phlegm, wheeze, asthma } \\
\text { (among females) and allergy, } \\
\text { p }<0.05\end{array}$ \\
\hline $\begin{array}{l}\text { DALES [19] } \\
1991 \\
\text { Canada } \\
\text { (six regions) }\end{array}$ & $\begin{array}{l}14,799,>20 \text { yrs, cross- } \\
\text { sectional questionnaire }\end{array}$ & $\begin{array}{l}\text { Four definitions by } \\
\text { reporting: } \\
\text { 1. Moisture (wet or } \\
\text { damp spots) } \\
\text { 2. Mould (mould or } \\
\text { mildew growing) } \\
\text { 3. Flooding (leak, flooding } \\
\text { or water damage) } \\
\text { 4. Dampness and mould } \\
\text { (presence of } 1,2 \text { or } 3 \text { ) }\end{array}$ & $\begin{array}{l}\text { Definition 1. } 14 \\
\text { Definition 2. } 27 \\
\text { Definition 3. } 19 \\
\text { Definition 4. } 38\end{array}$ & $\begin{array}{l}\text { Upper respiratory symptoms, } \\
\text { lower respiratory symptoms, } \\
\text { chronic respiratory disease, } \\
\text { asthma, eye irritation and } \\
\text { other symptoms, } p<0.01\end{array}$ \\
\hline $\begin{array}{l}\text { BRUNEKREEF [16] } \\
1992 \\
\text { Helmond, The } \\
\text { Netherlands }\end{array}$ & $\begin{array}{l}3,344 \text { adults, cross- } \\
\text { sectional questionnaire }\end{array}$ & $\begin{array}{l}\text { Three definitions by } \\
\text { reporting: } \\
\text { 1. Damp stains } \\
\text { 2. Visible mould growth } \\
\text { 3. Home dampness ( } 1 \\
\text { and/or } 2 \text { ) }\end{array}$ & $\begin{array}{l}\text { Definition 1. } 24 \\
\text { Definition 2. } 15 \\
\text { Definition 3. } 25\end{array}$ & $\begin{array}{l}\text { Cough, phlegm, wheeze } \\
\text { and lower respiratory } \\
\text { symptoms, } p<0.01 \text { (asthma was } \\
\text { near the level of significance) }\end{array}$ \\
\hline
\end{tabular}

Damp and mouldy homes occur even in Scandinavia, although the buildings are well-insulated, the heating season is long (up to 8 months), and the indoor air is relatively dry for most of the year [21]. However, in subarctic regions, mould problems may have their own special features, due to the airtightness of the houses and the long hours spent indoors during the cold weather.

The aim of this study was to determine the prevalence of mould problem homes and their possible association with respiratory diseases and symptoms among a randomly selected adult population living in the subarctic climate of Eastern Finland.

\section{Subjects and methods}

The study material was collected as a part of the Finriskstudy, which was carried out in the spring of 1992 by the National Public Health Institute. The Finrisk-study is a survey of risk factors of cardiovascular diseases and nutrition in adults living in Eastern and South-western Finland, and in the area of the capital city [22]. Crosssectional random sampling was drawn from the national population register.

A questionnaire on the condition of the home and respiratory diseases and symptoms was sent by mail to 2,000 males and females aged 24-65 yrs living in Eastern Finland. The respondent rate was $76 \%(n=1,521)$. In the analyses, the 1,460 individuals who had responded to all the questions on dampness and mould were included.

The definition of a home with damp and mould problems was based on four questions: 1) have you previously had or are you at present able to see visible mould growth on the walls or the structure of your home? 2) have you previously or are you currently aware of an odour of mould or cellar-like fusty air in your home? 3) have you previously, or do you currently notice moisture stains in the structures of your home? and 4) have you previously or are you currently suffering from water/ moisture damage in your home? 
Based on the answers to these questions, the following definitions of a home with damp or mould problems were formed: Definition 1) the answer "yes" to Question 1; Definition 2) the answer "yes" to Question 2; Definition 3) the answer "yes" to any of Questions 1, 2 or 3; and Definition 4: the answer "yes" to any of Questions 1, 2, 3 or 4 .

A person was defined as being atopic if he/she had answered "yes" to at least one of the following questions: 1) Have you ever had asthma diagnosed by a physician? 2) Have you ever had hay fever or other allergic rhinitis? 3) Have you had infantile eczema or atopic eczema in the hollows of elbows or knees?

We tried to control for any possible reporting bias by means of control questions on lumbar backache and recurrent stomach ache. Positive answers to either of these questions were used to build a "complainer" variable. For the same purpose, we also used questions on stress and depression. The "stress and depression" variable was compiled by combining one question and three statements of mental health. Firstly, "Have you been stressed in the last month?"; secondly, "It seems to me impossible to achieve the goals in life which I would like to reach for"; thirdly, "The future seems to me hopeless and I cannot believe that things are going to become any better"; and finally, "I feel that I don't have any proper friends".

The prevalence of reported infections and symptoms was analysed with logistic regression models [23]. Odds ratios were adjusted for age, sex, smoking, education and type of dwelling.

\section{Results}

The prevalences of damp and mould problem homes varied according to the definition used. The prevalences were: Definition 1 ) visible mould 3.7\%; Definition 2) odour of mould 5.5\%; Definition 3) moisture stains or visible mould or odour of mould $14.7 \%$; and Definition 4) water/moisture damage or moisture stains or visible mould or odour of mould $23.9 \%$.

Subjects living in homes with damp or mould problems (Definition 4) were slightly older, were better educated and more often lived in a single-family dwelling (table 2). Other differences were minor.

One possible confounder, chronic illness diagnosed by physician, was also analysed with Definition 4 . Chronic illnesses included: hypertension, heart failure, angina pectoris, cancer, bronchial asthma, emphysema, chronic bronchitis, gall stones, cholecystitis, rheumatoid arthritis, other articular disease, chronic back pain, chronic urinary tract infection and chronic pyelonephritis. No differences were found between the tenants of "mould problem" or "healthy" homes.

Bronchitis, atopy and allergic rhinitis were significantly more prevalent in inhabitants of damp or mouldy homes $(\mathrm{p}<0.001)$ when Definition 4 was used and age, sex, tobacco smoking, education years and dwelling type were adjusted for with a logistic regression model. Symptoms such as phlegm $(\mathrm{p}<0.05)$, rhinitis $(\mathrm{p}<0.001)$, eye irritation $(\mathrm{p}<0.01)$, fever and chills $(\mathrm{p}<0.01)$, impaired sense of smell $(\mathrm{p}<0.05)$ and hoarseness $(\mathrm{p}<0.01)$ were also more prevalent among subjects reporting home dampness or moulds (table 3 ). Fatigue/tiredness ( $<<0.001$ ),
Table 2. - Background variables

\begin{tabular}{|c|c|c|c|}
\hline & \multicolumn{3}{|c|}{$\begin{array}{l}\text { Living in a home with } \\
\text { damp or mould problem } \\
\text { Definition } 4 \text {, see text) }\end{array}$} \\
\hline & $\begin{array}{c}\text { No } \\
\%\end{array}$ & $\begin{array}{l}\text { Yes } \\
\%\end{array}$ & $\begin{array}{c}\mathrm{p}- \\
\text { value }\end{array}$ \\
\hline \multirow[t]{2}{*}{ Female gender } & $(n=1,126)$ & $(n=334)$ & \multirow{3}{*}{0.51} \\
\hline & 53 & 55 & \\
\hline Age group & $(\mathrm{n}=1,126)$ & $(n=334)$ & \\
\hline $25-34$ yrs & 25 & 23 & \multirow{3}{*}{0.30} \\
\hline $35-44$ yrs & 24 & 29 & \\
\hline $45-54$ yrs & 25 & 27 & \\
\hline $55-64 \mathrm{yrs}$ & 26 & 22 & \multirow{6}{*}{0.08} \\
\hline Marital status & $(\mathrm{n}=1,010)$ & $(n=310)$ & \\
\hline Married or common-law married & 77 & 81 & \\
\hline Unmarried & 12 & 8 & \\
\hline Legally separated or divorced & 8 & 8 & \\
\hline Widow or widower & 4 & 2 & \\
\hline Education & $(\mathrm{n}=1,010)$ & $(n=310)$ & \multirow{5}{*}{0.76} \\
\hline$<8$ yrs & 16 & 12 & \\
\hline $8-9$ yrs & 29 & 26 & \\
\hline $10-12$ yrs & 27 & 31 & \\
\hline$>12$ yrs & 28 & 31 & \\
\hline Occupation & $(\mathrm{n}=1,010)$ & $(n=310)$ & \multirow{5}{*}{0.44} \\
\hline Agriculture or forestry & 9 & 11 & \\
\hline Industry or construction work & 17 & 11 & \\
\hline \multirow{2}{*}{$\begin{array}{l}\text { Service sector, housewife, student } \\
\text { pensioner or unemployed }\end{array}$} & & & \\
\hline & 74 & 79 & \\
\hline Dwelling place & $(\mathrm{n}=1,011)$ & $(n=310)$ & \multirow{5}{*}{0.99} \\
\hline Central part of the town & 13 & 13 & \\
\hline Housing estate in the town & 38 & 36 & \\
\hline Population centre in the country & 24 & 24 & \\
\hline Scattered settlement in the country & 26 & 28 & \\
\hline Type of dwelling & $(\mathrm{n}=1,117)$ & $(n=334)$ & \multirow{4}{*}{0.38} \\
\hline Detached house & 54 & 63 & \\
\hline Terraced house & 16 & 15 & \\
\hline Block of flat & 30 & 22 & \\
\hline Ownership of the dwelling & $(\mathrm{n}=1,011)$ & $(n=310)$ & \multirow{4}{*}{1.00} \\
\hline Owner-occupied flat or house & 79 & 79 & \\
\hline Rented flat & 21 & 21 & \\
\hline Smoking & $(\mathrm{n}=1,126)$ & $(n=334)$ & \\
\hline Never smoked & 41 & 42 & \multirow{3}{*}{0.89} \\
\hline Last more than half year ago & 21 & 23 & \\
\hline Last less than half year ago & 38 & 35 & \\
\hline
\end{tabular}

difficulties in concentration $(\mathrm{p}<0.01)$ and "control" variables, lumbar backache $(\mathrm{p}<0.01)$ and recurrect stomach ache $(\mathrm{p}<0.001)$ were also more prevalent (table 3$)$.

After adjusting for atopy, the following associations remained significant: bronchitis $(\mathrm{p}<0.001)$; rhinitis $(\mathrm{p}<0.05)$; fever and chills $(\mathrm{p}<0.05)$; hoarseness $(\mathrm{p}<0.05)$; fatigue/tiredness $(\mathrm{p}<0.001)$; difficulties in concentration $(\mathrm{p}<0.05)$; lumbar backache $(\mathrm{p}<0.05)$; and recurrent stomach ache $(\mathrm{p}<0.01)$.

There were no differences in the prevalence of "wheezing" and "difficulty in breathing" between dwellers in homes with or without mould. When Definition 2, "odour of mould", was used (data not shown), the results differed in the risk of tonsillitis, asthma, atopic eczema, chronic bronchitis and allergic eczema. According to Definition 2, other new associations were observed for common cold and cough. The number of subjects exposed to damp or mould by applying Definition 2 was fairly small $(\mathrm{n}=80)$. After excluding the "complainers", only eye irritation and fatigue remained significant, while after excluding the "stressed and depressive, the main findings were unchanged (table 4). 
Table 3. - Respiratory infections and symptoms and living in a home with damp or mould problem

\begin{tabular}{|c|c|c|c|c|}
\hline \multirow[b]{2}{*}{ Disease or symptom } & \multicolumn{4}{|c|}{ Living in a home with damp or mould problem (Definition 4, see text) } \\
\hline & $\begin{array}{c}\text { No } \\
(\mathrm{n}=1,126)\end{array}$ & $\begin{array}{c}\text { Yes } \\
(\mathrm{n}=334)\end{array}$ & AOR & $95 \% \mathrm{CL}$ \\
\hline Common cold times $\cdot \mathrm{yr}^{-1}$ & 1.26 & 1.39 & 1.68 & $0.96-1.21$ \\
\hline Tonsillitis times $\mathrm{yr}^{-1}$ & 0.07 & 0.05 & 0.68 & $0.38-1.21$ \\
\hline Otitis media times $\cdot \mathrm{yr}^{-1}$ & 0.06 & 0.07 & 1.12 & $0.66-1.89$ \\
\hline Sinusitis times $\cdot \mathrm{yr}^{-1}$ & 0.20 & 0.27 & 1.24 & $0.95-1.62$ \\
\hline Bronchitis times $\cdot \mathrm{yr}^{-1}$ & 0.11 & 0.23 & $2.04 * * *$ & $1.49-2.78$ \\
\hline Pneumonia times $\cdot \mathrm{yr}^{-1}$ & 0.01 & 0.01 & 2.30 & $0.66-8.03$ \\
\hline Asthma \% & 5.9 & 6.1 & 1.02 & $0.60-1.72$ \\
\hline Atopy $\%$ & 35.0 & 47.0 & $1.63 * * *$ & $1.26-2.10$ \\
\hline Allergic rhinitis \% & 21.6 & 31.9 & $1.66^{* * *}$ & $1.25-2.19$ \\
\hline Atopic eczema \% & 19.2 & 24.2 & 1.31 & $0.97-1.76$ \\
\hline Chronic bronchitis \% & 8.7 & 12.0 & 1.51 & $0.96-2.35$ \\
\hline Cough \% & 16.2 & 20.1 & 1.37 & $0.99-1.88$ \\
\hline Phlegm \% & 18.8 & 23.6 & $1.36^{*}$ & $1.01-1.85$ \\
\hline Rhinitis \% & 42.8 & 56.1 & $1.69 * * *$ & $1.31-2.18$ \\
\hline Eye irritation \% & 34.1 & 44.8 & $1.52 * *$ & $1.18-1.96$ \\
\hline Allergic eczema \% & 13.6 & 16.5 & 1.21 & $0.86-1.71$ \\
\hline Fever and chills \% & 15.0 & 21.6 & $1.61 * *$ & $1.17-2.22$ \\
\hline Impaired sense of smell \% & 6.0 & 9.4 & $1.71^{*}$ & $1.05-2.78$ \\
\hline Nosebleed \% & 1.0 & 1.7 & 2.06 & $0.68-6.22$ \\
\hline Dry or sore throat $\%$ & 4.5 & 6.9 & 1.68 & $0.97-2.89$ \\
\hline Hoarseness \% & 4.7 & 10.0 & $2.23 * *$ & $1.37-3.63$ \\
\hline Fatigue, tiredness $\%$ & 22.6 & 34.5 & $1.81 * * *$ & $1.37-2.39$ \\
\hline Headache $\%$ & 11.0 & 13.2 & 1.20 & $0.81-1.77$ \\
\hline Nausea \% & 2.4 & 4.1 & 1.80 & $0.87-3.71$ \\
\hline Difficulties in concentration $\%$ & 5.2 & 10.0 & $2.17 * *$ & $1.35-3.50$ \\
\hline Other symptoms \% & 5.9 & 6.8 & 1.03 & $0.58-2.04$ \\
\hline Lumbar backache \% & 56.1 & 66.1 & $1.49 * *$ & $1.15-1.93$ \\
\hline Recurrent stomachache \% & 19.8 & 28.7 & $1.65^{* * *}$ & $1.24-2.20$ \\
\hline
\end{tabular}

AOR: odds ratios adjusted for age, sex, smoking, education and type of dwelling; 95\% CL: 95\% confidence limits. *,**, $*_{* *}: \mathrm{p}<0.05, \mathrm{p}<0.01, \mathrm{p}<0.001$ comparing positive and negative responses.

Table 4. - "Noncomplainers" and "no stress and depression" and the association between respiratory infections and symptoms and living in a home with damp or mould problem

\begin{tabular}{|c|c|c|c|c|c|c|c|c|c|}
\hline \multirow[b]{3}{*}{ Disease or symptom } & \multirow{2}{*}{\multicolumn{3}{|c|}{$\begin{array}{l}\text { Damp or mould problem home } \\
\text { (Definition 2, see text) }\end{array}$}} & \multicolumn{3}{|c|}{ "Noncomplainers"\# } & \multicolumn{3}{|c|}{ "No stress and depression"\# } \\
\hline & & & & $\begin{array}{r}\text { Damp or } n \\
\text { (Defil }\end{array}$ & $\begin{array}{l}\text { uld prob } \\
\text { tion } 4 \text {, se }\end{array}$ & $\begin{array}{l}\text { m home } \\
\text { text) }\end{array}$ & $\begin{array}{r}\text { Damp or } \mathrm{m} \\
\text { (Defi }\end{array}$ & $\begin{array}{l}\text { uld proble } \\
\text { tion } 4 \text {, se }\end{array}$ & $\begin{array}{l}\text { m home } \\
\text { text) }\end{array}$ \\
\hline & $\begin{array}{c}\text { No } \\
(\mathrm{n}=1,380)\end{array}$ & $\begin{array}{c}\text { Yes } \\
(\mathrm{n}=80)\end{array}$ & AOR & $\begin{array}{c}\text { No } \\
(\mathrm{n}=390)\end{array}$ & $\begin{array}{c}\text { Yes } \\
(n=92)\end{array}$ & AOR & $\begin{array}{c}\text { No } \\
(\mathrm{n}=799)\end{array}$ & $\begin{array}{c}\text { Yes } \\
(\mathrm{n}=213)\end{array}$ & AOR \\
\hline Common cold times $\cdot \mathrm{yr}^{-1}$ & 1.26 & 1.65 & $1.25 *$ & 1.05 & 0.99 & 0.94 & 1.26 & 1.43 & 1.11 \\
\hline Bronchitis times $\cdot \mathrm{yr}^{-1}$ & 0.13 & 0.23 & $1.83 *$ & 0.08 & 0.14 & 1.57 & 0.10 & 0.23 & $2.17 * * * *$ \\
\hline Atopy \% & 37 & 46 & 1.36 & 29 & 36 & 1.34 & 34 & 48 & $1.78^{* * * *}$ \\
\hline Allergic rhinitis \% & 23 & 34 & 1.56 & 17 & 21 & 1.37 & 21 & 30 & $1.63 * *$ \\
\hline Cough \% & 16 & 24 & $1.73 *$ & 11 & 13 & 1.48 & 14 & 20 & $1.59 *$ \\
\hline Phlegm \% & 20 & 29 & $1.70 *$ & 13 & 13 & 0.94 & 18 & 25 & $1.64 * *$ \\
\hline Rhinitis \% & 44 & 65 & $2.34 * * *$ & 32 & 36 & 1.21 & 40 & 54 & $1.79 * * * *$ \\
\hline Eye irritation \% & 36 & 48 & 1.58 & 21 & 31 & $1.69 *$ & 31 & 44 & $1.74 * * * *$ \\
\hline Fever and chills \% & 16 & 24 & $1.75^{*}$ & 9 & 10 & 1.19 & 12 & 18 & $1.55^{*}$ \\
\hline Impaired sense of smell & $\%$ & 11 & 1.83 & 4 & 3 & 0.61 & 4 & 9 & $2.37 * *$ \\
\hline Hoarseness \% & 6 & 12 & $2.18 *$ & 3 & 1 & 0.93 & 3 & 8 & $3.10^{* *}$ \\
\hline Fatigue, tiredness $\%$ & 24 & 38 & $1.82 *$ & 12 & 20 & $2.06^{*}$ & 19 & 23 & 1.24 \\
\hline Poor concentration $\%$ & 6 & 9 & 1.72 & 3 & 1 & 0.39 & 4 & 4 & 1.13 \\
\hline Lumbar backache \% & 57 & 72 & $1.90 *$ & & & & 53 & 65 & $1.66^{* *}$ \\
\hline Recurrent stomachache $\%$ & $\% \quad 21$ & 35 & $2.13 * *$ & & & & 18 & 23 & 1.43 \\
\hline
\end{tabular}

\#: see Subjects and Methods. AOR: odds ratio adjusted for age, sex, smoking, education and dwelling type. *: $\mathrm{p}<0.05 ; * *$ : $\mathrm{p}<0.01 ; * * *: \mathrm{p}<0.001$ comparing positive and negative responses.

\section{Discussion}

The prevalence of mouldy homes depended on the definition used. An objective measurement or definition of home dampness and mould problem is important for the definition of exposure in future research. According to preliminary findings, mould problems are more commonly detected by an expert's walk-through examination rather than being reported by the residents of the homes themselves [7].

In the present study, self-reported home dampness or mould problems were associated with an increased 
prevalence of reported respiratory infections and respiratory symptoms. However, using different definitions did not essentially cause any change in the pattern of symptoms or respiratory diseases associated with exposure to damp or mould problem houses. In the present study, no objective measures of mould problems or respiratory infections or diseases were made. The main findings remained after adjusting for confounding factors and possible reporting bias. A similar association has also been reported in several other studies (table 1). The only report where this association was not verified for adults, though it was present in children, was that of MARTIN et al. [10]. In their study, the socioeconomic structure of the study population was not equivalent to the average of the country; unemployment was high and a third of all households were receiving supplementary benefit.

Reporting bias has been investigated in studies by Platt et al. [12] and Dales et al. [19]. They inquired about other symptoms and diseases as control variables. In both studies, the main results were unchanged after adjusting for this bias in the analysis. It may also be necessary to discuss possible underreporting of moulds, which could be caused by feeling of shame of the mould problem in the house. For example, the odour of mould may be underreported for this reason.

In conclusion, the results of our study indicate that there is an association between increased risk of respiratory symptoms and infections and living in a home with damp or mould problems. Further research is needed to study the aetiology and causes of the symptoms and infections, as well as possible interactions between moulds and other indoor air pollutants, e.g. viruses, bacteria, mites, animal dander and volatile organic compounds.

\section{References}

1. Samet JM, Marbury MC, Spengler JD. Health effects and sources of indoor air pollution. Part II. Am Rev Respir Dis 1988; 137: 221-242.

2. Arundel AV, Sterling EM, Biggin JH, Sterling TD. Indirect health effects of relative humidity in indoor environments. Environ Health Perspect 1986; 65: 351-361.

3. Spengler JD, Sexton K. Indoor air pollution: a public health perspective. Science 1983; 221: 9-17.

4. Reponen T, Nevalainen A, Raunemaa T. Bioaerosol and particle mass levels and ventilation in Finnish homes. Environ Int 1989; 15: 203-208.

5. Pasanen A-L, Pasanen P, Jantunen MJ, Kalliokoski P. Significance of air humidity and air velocity for fungal spore release into air. Atmos Environ 1991; 25A: 459-462.

6. Pasanen AL, Kalliokoski P, Pasanen P. Laboratory studies on the relationship between fungal growth and atmospheric temperature and humidity. Environ Int 1991; 17: 225-228.

7. Nevalainen A, Partanen P, Hyvärinen A, et al. Building moisture investigation: back to basics in identifying microbial problems. In: Morawska L, Bofinger ND, Maroni M, eds. Indoor Air: an Integrated Approach. 1st edn. Exeter, BPC Wheatons Ltd, 1995; pp. 485-488.

8. Burr ML, St Leger AS, Yarnell JWG. Wheezing, dampness, and coal fires. Community Med 1981; 3: 205-209.

9. Burr ML, Mullins J, Merret TG, Stott NCH. Asthma and indoor mould exposure (Abstract). Thorax 1985; 40: 688 .

10. Martin CJ, Platt SD, Hunt SM. Housing conditions and ill health. Br Med J 1987; 294: 1125-1127.

11. Strachan DP. Damp housing and childhood asthma: validation of reporting of symptoms. Br Med J 1988; 297: 1223-1226.

12. Platt SD, Martin CJ, Hunt SM, Lewis CW. Damp housing, mould growth, and symptomatic health state. $\mathrm{Br}$ Med J 1989; 298: 1673-1678.

13. Strachan DP, Sanders CH. Damp housing and childhood asthma: respiratory effects of indoor air temperature and relative humidity. J Epidemiol Commun Health 1989; 43: 7-14.

14. Strachan DP, Flannigan B, McCabe EM, McGarry F. Quantification of airborne moulds in the homes of children with and without wheeze. Thorax 1990; 45: 382-387.

15. Waegemaekers M, van Wageningen, Brunekreef B, Boleij JSM. Respiratory symptoms in damp homes. Allergy 1989; 44: 192-198.

16. Brunekreef B. Damp housing and adult respiratory symptoms. Allergy 1992; 47: 498-502.

17. Brunekreef B, Dockery DW, Speizer FE, Ware JH, Spengler JD, Ferris BG. Home dampness and respiratory morbidity in children. Am Rev Respir Dis 1989; 140: 1363-1367.

18. Spengler J, Neas L, Nakai S, et al. Respiratory symptoms and housing characteristics. Indoor Air 1994; 4: 72-82.

19. Dales RE, Burnett R, Zwanenburg H. Adverse health effects among adults exposed to home dampness and molds. Am Rev Respir Dis 1991; 143: 505-509.

20. Holmberg K. - Hälsorisker vid exponering i mögelskadade byggnader. Läkartidningen 1984; 81: 3327-3333.

21. Husman T, Koskinen O, Hyvärinen A, Reponen T, Ruuskanen J, Nevalainen A. Respiratory symptoms and infections among residents in dwellings with moisture problems or mold growth. In: Jaakkola JJK, llmarinen R, Seppänen O, eds. Indoor Air 1993. Proceedings of the 6th International Conference on Indoor Air Quality and Climate, Helsinki, July 4-8, 1993; 1: pp. 171-174.

22. Vartiainen E, Puska P, Jousilahti P, Korhonen HJ, Tuomilehto J, Nissinen A. Twenty year trends in coronary risk factors in North Karelia and in other areas of Finland. Int J Epidemiol 1994; 23: 495-504.

23. Kleinbaum DG, Kupper LL, Muller KE. Applied regression analysis and other multivariable methods. 2 edn. Boston, PWS-KENT Publishing Co., 1988; 497-512. 